\title{
READERS
Insight
}

\author{
Journal of Economic Info (JEI) \\ ISSN:2313-3376 \\ www.readersinsight.net/jei
}

\section{Relationship Analysis of Islamic Banking between Malaysia and Pakistan}

\author{
Khurrum Faisal Jamal \\ PhD Scholar, Institute of Islamic Banking, University of Management and Technology Lahore, Pakistan \\ *Corresponding author: Khuram.ahmad@yahoo.com
}

\begin{abstract}
Islamic banking is basically a system of financial intermediation, its primary objective is to avoid receipt and payment of interest. Islam does not only prohibit dealing with interest but also with liquor, pork, gambling pornography and any other thing which are considered haram according to Shariah. The objectives of the research is to study and describe the Islamic financing techniques used by Islamic banking institutions in Malaysia and Pakistan. For this research seven variables Promotion, Product, Preference, Knowledge, Performance, Problem and Infrastructure was taken. Qualitative technique was used to answer the research objective. The findings of research indicate that lack of awareness of Islamic banking is very high in Pakistan as compared to Malaysia. A few promotions were used by Islamic banks in Pakistan while in Malaysia customers are knowledgeable about Islamic banking because banks promote them aggressively. There is a need of government and education sector support to promote Islamic banking in both countries. The study also found that Islamic banks in Malaysia have large range of products as compared to Pakistan. The practitioners from both countries are agreed at this point that BBA, ljarah and Murabaha are more profitable and less risky than Musharaka and Mudaraba. The Islamic banking products are almost used for same purposes in both countries while some differences are also exists.
\end{abstract}

Keywords: Islamic Finance, Comparative Study, Malaysia, Pakistan

\section{ARTICLE INFORMATION}

Received: 8 February 2018

Revised: 12 April 2018

Accepted: 25 April 2018

DOI: $10.31580 /$ jei.v5i2.112

\section{Introduction}

\section{Overview of Islamic Banking}

Islamic banking is basically a system of financial intermediation, its primary objective is to avoid receipt and payment of interest. Islam does not only prohibit dealing with interest but also with liquor, pork, gambling, pornography and any other thing which are considered haram according to shariah. The first modern experiment with Islamic banking was undertaken in Egypt. The pioneering effort, in Islamic banking was made by Ahmad El Najjar. He first established a savings bank based on profit-sharing in the Egyptian town of Mit Ghamr in 1963. This experiment was successful and since then until 1967 there were nine such banks in the country.

The Nasir Social Bank, established in Egypt in 1971, was declared an interest-free commercial bank. In the seventies, a number of Islamic banks came into existence in the Middle East, for example the Dubai Islamic Bank (1975), the Faisal Islamic Bank of Sudan (1977), the Faisal Islamic Bank of Egypt (1977), and the Bahrain Islamic Bank (1979), to mention a few. The Islamic Development Bank was established in 1974 by the Organization of Islamic Countries (OIC).

In 2017, Islamic banks recorded higher pre-tax profits of RM6.7 billion (2016: RM5.6 billion). This was driven mainly by an increase in net financing income derived from term financing for the purchase of properties. Returns on assets and equity were stable at $1.1 \%$ and 14.3\% (2016: $1 \%$ and $13.1 \%$ ) respectively. The countries where Islamic financial institutes are functioning include: Albania, Algeria, Australia, Bahamas, Bahrain, Bangladesh, British Virgin Islands, Brunei, Canada, Cayman Island, North Cyprus, Djibouti, Egypt,
France, Gambia, Germany, Guinea, India, Indonesia, Iran, Iraq, Italy Ivory Coast, Jordan, Kazakhstan, Kuwait, Lebanon, Luxembourg, Malaysia, Mauritania, Morocco, The Netherlands, Niger, Nigeria, Oman, Pakistan, Palestine, Philippines, Qatar, Russia, Saudi Arabia, Senegal, South Africa, Sri Lanka, Sudan, Switzerland, Tunisia, Turkey, Trinidad \& Tobago, United Arab Emirates, United Kingdom, United States and Yemen. The main centers of Islamic world are Middle East, Malaysia, Dubai and the U.K. Both the Muslims and non Muslims are included in the customer's profile of Islamic financial institutions.

\section{Islamic Banking in Pakistan}

Islamic Banking in Pakistan is not a new concept. The country is already familiar up to some extent. They started effort to eliminate riba in 1970s but most promising efforts were taken in early 1980s, until 1985, the Islamic Banking had government support and flourished rapidly. However, after 1985, factors such as lack of commitment from the public and government, political instability, inadequate judicial system and absence of Shariah compliance mechanism in the banks discouraged further research and development in this field. In November, 1991 the existing mark up system used by banks was declared un-Islamic by the Federal Shariat Court (FSC). The Commission for the Transformation of Financial System (CTFS) in the State Bank was formed in January 2000. The CTFS constituted a committee for the development of financial instruments and standardized documents to prepare model agreements and financial instruments for an Islamic banking system. This Commission plays a vital role to promote and develop Islamic banking system in Pakistan. As a result of these efforts, in 2001, an Islamic Banking Division was 
established in the Banking Policy Department at SBP. It was later expanded to a full-fledged Islamic Banking Department (IBD) in 2003.

In December 2001, State Bank of Pakistan (SBP) issued the detailed criteria for the establishment of Islamic commercial banks in the private sector. In order to be incorporated as an Islamic bank, on January, 2003 the state bank had made three broad strategies which, include: (i) to establish either full-fledged Islamic banks in the private sector; (ii) to set up Islamic banking subsidiaries (iii) to stand alone as Islamic banking branches of the existing commercial banks. AlMeezan Investment Bank Limited applied under the criteria issued by SBP to convert itself into an Islamic commercial bank. It was issued with the license in the name of Meezan Bank Limited to operate as a full-fledged Islamic bank in January 2002.

Market share of Islamic banking assets and deposits in the overall banking industry was recorded at 13.5 percent and 14.6 percent, respectively by end March, 2018. The network of Islamic banking industry consisted of 21 Islamic banking institutions; 5 full-fledged Islamic banks and 16 conventional banks having standalone Islamic banking branches by end March, 2018. Branch network of Islamic banking industry stood at 2,589 (spread across 111 districts) by end March, 2018. The number of Islamic banking windows operated by conventional banks having standalone Islamic banking branches was recorded at 1,283 .

\section{Islamic Banking in Malaysia}

Malaysia is considered the hub of Islamic banking and there is separate Islamic legislation and banking regulations exist side-by-side. The Islamic Banking Act (IBA) came into effect on 7 April 1983. This Act provides legal basis for the establishment of Islamic banks. The central bank of Malaysia, Bank Negare Malaysia (BNM) supervise and regulate Islamic banks under Islamic Banking Act (IBA). The first Islamic bank was established in Malaysia on 1 July 1983 with the name of Bank Islam Malaysia Berhad (BIMB). The bank was listed on the main board of the Kuala Lumpur Stock Exchange on 17 January 1992. Currently in the year 2016, there are 16 full-fledged Islamic banks operating in Malaysia, a healthy $10.3 \%$ growth in 2017 and was substantially ahead of conventional banks' $1.7 \%$ growth during the same period.

In Malaysia the Islamic Interbank Money Market (IIMM) was introduced on 4 January 1994. In terms of products and services, there are more than 40 Islamic financial products and services that are offered by the banks using various Islamic concepts such as Mudharabah, Musharakah, Murabahah, Bai' Bithaman Ajil (Bai' Muajjal), Ijarah, Qardhul Hasan, Istisna' and Ijarah Thumma AlBai'.and others.

Many studies have been done on Islamic banking. Some studies are based on comparison of Islamic banking practices and conventional banking. Other studies covered profitability determinants of Islamic banks. However hardly any studies had been published on comparative study between Pakistan and Malaysia. The objectives of the research is to study and describe the Islamic financing techniques used by Islamic banking institutions in Malaysia and Pakistan. For this research seven variables Promotion, Product, Preference, Knowledge, Performance, Problem and Infrastructure was taken.

\section{REVIEW OF LITERATURE:}

With reference to interest theory Qurashi (1946) considered banking as a social service and government should support this area as supported to others. He was in favor of partnerships between banks and businessmen as an alternative because the bank could neither pay any interest to neither account holders nor charge any interest on loans advanced.

The principle of Mudaraba based on Shariah was invoked systematically by Uzair (1955). His principal contribution lay in suggesting Mudaraba as the main premise for 'interestless banking'. However, his argument that the bank should not make any capital investment with its own deposits rendered his analysis somewhat impractical.

Al-Arabi (1966) envisaged a banking system with Mudaraba as the main pivot. He was actually advancing the idea of a two-tier Mudaraba which would enable the bank to mobilize savings on a Mudaraba basis, allocating the funds so mobilized also on a Mudaraba basis.

Irshad (1964) also spoke of mudaraba as the basis of Islamic banking, but his concept of mudaraba was quite different from the traditional one in that he thought of capital and labour (including entrepreneurship) as having equal shares in output, thus sharing the losses and profits equally. This actually means that the owner of capital and the entrepreneur have a fifty-fifty share in the profit or loss as the case may be, which runs counter to the Shariah position. Irshad envisaged two kinds of deposit accounts. The first sounded like current deposits in the sense that it would be payable on demand, but the money kept in this deposit would be used for social welfare projects, as the depositors would get zero return. The second one amounted to term deposits which would entitle the depositors to a share in the profits at the end of the year proportionately to the size and duration of the deposits. He recommended the setting up of a Reserve Fund which would absorb all losses so that no depositor would have to bear any loss. According to Irshad, all losses would be either recovered from the Reserve Fund or borne by the shareholders of the bank.

A pioneering attempt at providing a fairly detailed outline of Islamic banking was made in Urdu by Siddiqi in 1968. His Islamic banking model was based on Mudaraba and shirka (partnership or Musharaka as it is now usually called). His model was essentially one based on a two-tier Mudaraba financier-entrepreneur relationship, but he took pains to describe the mechanics of such transactions in considerable detail with numerous hypothetical and arithmetic examples. He classified the operations of an Islamic bank into three categories: services based on fees, commissions or other fixed charges; financing on the basis of Mudaraba and partnership; and services provided free of charge. He therefore tended to downplay the role of Islamic banks in providing consumption loans, but he suggested limited overdraft facilities without interest. He even considered a portion of the fund being set aside for consumption loans, repayment being guaranteed by the State. He also suggested that consumers buying durables on credit would issue 'certificates of sale' which could be encashed by the seller at the bank for a fee. It was then the seller not the buyer who would be liable as far as the bank was concerned. However, the principles of Murabaha and Bai' Muajjal were not invoked.

In this context, reference may also be made to a proposal by Uzair (1982) that the central bank should acquire an equity stake in commercial banking by holding, say, 25 per cent of the capital stock of the commercial banks. The rationale behind this proposal was that it would give the central bank access to a permanent source of income so that it could effectively act as lender of last resort.

It emerges from all this that Islamic banking has three distinguishing features: (a) it is interest-free, (b) it is multi-purpose and not purely commercial, and (c) it is strongly equity-oriented. A recent International Monetary Fund study by Iqbal and Mirakhor (1987) has found Islamic banking to be a viable proposition that can result in efficient resource allocation. The study suggests that banks in an Islamic system face fewer solvency and liquidity risks than their conventional counterparts.

The Report of Pakistan's Council of Islamic Ideology (CII 1983) has suggested that the respective capital contributions of parties can be converted to a common denominator by multiplying the amounts provided with the number of days during which each component, such as the firm's own equity capital, its current cash surplus and suppliers' credit was actually deployed in the business, i.e., on a daily product basis. As for deposits, profits (net of administrative expenses, taxes, and appropriation for reserves) would be divided between the shareholders of the bank and the holders of deposits, again on a daily product basis. 
Ahmad Kaleem \& Mansor Md Isa has also mentioned few arguments from different scholars about the relationship between Islamic and conventional banking in their article. Ariff (1995) in his literature survey on Islamic banking found that Islamic banks around the world offer three main types of depository services such as current account, savings accounts and the investment accounts. Current accounts and savings guarantee depositors the nominal value of the deposit, but provide no guarantee on returns. The investment accounts operate fully under the profit/loss sharing (PLS) scheme where capital is not guaranteed neither any pre-fixed returns. Ariff also observed considerable variations within Investment accounts.

Gafoor (2001) argued that Islamic jurists are only concerned that the element of risk should not be excluded from the financial transactions. Otherwise, it would no longer be one of business and trade, but of usury. Gafoor further argued that the profits would have accrued from one year to another according to the performance of the bank, not according to changes in interest rates.

A study made by Erol and El-Bdour (1989) indicated that Muslims patronized Islamic banks not specifically because of the religious factor, but more because of the returns they would receive from their investments. Depositors in Islamic countries also did not differentiate between the services offered by the conventional banks and the Islamic banks. They remarked that since religion is no longer the main factor in attracting depositors, Islamic banks should recognize that how the customers view their products and services. They should offer quality of service and products compatible with those offered by the commercial banks.

In Malaysia, Radiah (1993) observed that there are two main types of depositors among local Muslims. The first group represents those who strictly follow the religion in life and want to stick with Islamic banking at any cost. The second group consists of moderate Muslims. They give more priority to service quality and time value of their savings. Similar to this, Haron and Planisek (1994) found that profits and religion are the main motives behind depositing money with Islamic banks in Malaysia. They observed that only $40 \%$ of the Muslim customers give preferences to Islamic banking. The remaining majority including non-Muslim customers considers the time value as more important. They expect their banking transactions to be completed as fast as possible. Haron and Planisek also found that more than half of the Muslim and non-Muslim respondents indicated the possibility of establishing relationships with the Islamic banks if they have a complete understanding about their operations. The authors remarked that the top management of Islamic banks should realize the needs of time value of money and do not solely depend upon Muslims for deposits or as their fund users. They have to expand their base by including non-Muslims as potential customers. Gerrad and Cunningham (1997) in the case of Singapore also came out with similar types of observations. They found that both religion and profits are the reasons for Muslims maintaining relationships with Islamic banking.

\section{ISLAMIC FINANCIAL TECHNIQUES PRACTICED IN MALAYSIA AND PAKISTAN}

\section{Murabaha}

One of the most widely used instruments for short-term financing is based on the traditional notion of purchase finance. Murabaha means a sale of goods by a person to another under an arrangement whereby the seller is obliged to disclose to the buyer the cost of goods sold and buyer make payment either on deferred payment basis in terms of lump sum cash or installment basis. The difference between cost and sale price is profit for seller. Profit should be decided at the time of transaction and no change in the price is acceptable once the transaction made.

In Malaysia Murabaha is used for Working Capital Requirement, Letter of Credit Creation, Education Financing, Personal Financing, Floor Stock Financing, Commercial Papers and Export Credit Refinancing, Accepted Bills and Trust Receipt. Around 75 percent of
Islamic financial transactions are cost-plus sales. In Pakistan Murabaha is being used for Working Capital Requirement, Asset Financing, Import Financing, Export Financing (pre shipment), Consumer Goods Financing and Tour Package Financing.

\section{ljara}

Ijarah means to give something on rent. This is a leasing and hire purchase contract, where two parties involved, bank as ajir (lessor) and client as mustajir (lessee). The important feature of lease ijarah is the ownership of the asset remains with the bank (lessor) during the lease period. The client (lessee) must pay rent for possession of asset. Three parties can also be involved in Ijarah contract when bank purchase asset from supplier (vendor) and then lease to client. There are different options available at the time of expiry the lease asset. If the bank sells back the lease asset to the client we call Al-Ijarah-Tummal bai.

Bank can lease the asset to another client, sell in the secondary market and if end of ijarah period asset has no residual value then it can be given to the client as a gift. Ijarah Musharaka is also very popular type of ijarah which has the same features which we have discussed in diminishing Musharaka. Syndicated Ijarah is also important type to be discussed, if the financing require for a special purpose vehicle and bank is unable to finance individually then he invites other banks under Musharaka/Mudaraba contract to finance this lease contract jointly. Common usage of Ijarah are; Equipment, Machinery, Motor Vehicle and Consumer goods.

In Malaysia Ijarah Financing is used for Vehicle Leasing, Property Financing, and Plant \& Machinery Financing. While in Pakistan this contract is used for Vehicle Leasing and Equipment Financing.

\section{Mudaraba}

This is a profit and loss sharing principle, in which one party provides capital and other rendered services. The investor called rabbal-mal while the entrepreneur called Mudarib. Here former provide the funds and later is responsible for the management of the business and provide professional and technical services. Both share profit according to pre-agreed ratio but the loss is completely borne by the investor (capital provider) if this loss is not occurred due to the negligence of the agent. Mudaraba Financing is mostly used in equity based trustee partnership and in investment deposit account

There are two types of Mudaraba contract, in first contract the Mudarib has no take any investment decision the Rub-ul Maal may specify a particular business or place for investment. This type of Mudaraba contract called Al Mudaraba Al Muqayyada (restricted Mudaraba) In second type of Mudaraba contract the Mudarib has a right to take any investment decision which he consider better for business. This kind of contract called Al Mudarabah Al Mutlaqah (unrestricted Mudaraba). The maturity structure ranges from short to medium term and is more suitable for trade activities.

In Malaysia Mudaraba is used for Current Account, Saving Account, General Investment Account, Special Investment Account, Specific Investment Account and Negotiable Deposit Instruments. In Pakistan Mudaraba is used in Saving Account, Monthly Mudaraba Certificate, Dollar Mudaraba Certificate, and Islamic Investment Certificate

\section{Musharaka}

This is a profit and loss sharing Partnership contract; in other wards we can say joint venture. In Musharaka both the Bank and Customer contribute with capital and both are responsible for entrepreneurship. Profit are shared between them according to pre-agreed ratio while losses are shared strictly according to their capital contribution. Musharaka is used in letter of credit creation and for micro finance facility. Another famous type of Musharaka is Diminishing Musharaka that is used in house financing. Under this type of Musharaka the both Bank and Customer contribute with capital but the bank share divided 
into units and the customer must pay this share of units periodically to bank, so finally the bank's share will be zero and the customer will be the sole owner of the asset.

In Malaysia Musharaka is used for Corporate Financing. In Pakistan Diminishing Musharika is used for consumer financing like in house financing, Car financing and Fixed Asset Financing.

\section{Bay Salam}

Deferred-delivery sale (Bay' Salam) contracts, a deferred-delivery sale is similar to a forward contract where delivery of the product is in the future in exchange for payment on the spot market. In other wards Salam means a contract in which advance payment is made for goods to be delivered later on. The seller undertakes to supply some specific goods to the buyer at a future date in exchange of an advance price fully paid at the time of contract. It is necessary that the quality of the commodity intended to be purchased is fully specified leaving no ambiguity leading to dispute. The objects of this sale are goods and cannot be gold, silver or currencies. Barring this, Bai Salam covers almost everything, which is capable of being definitely described as to quantity, quality and workmanship. This is normally used to finance Agriculture sector, small and medium enterprises.

\section{Istisna}

It is a contractual agreement for manufacturing goods and commodities, allowing cash payment in advance and future delivery or a future payment and future delivery. Istisna' is a sale transaction where a commodity is transacted before it comes into existence. It is an order to a manufacturer to manufacture a specific commodity for the purchaser. The manufacturer uses his own material to manufacture the required goods.

In Istisna, price must be fixed with consent of all parties involved. All other necessary specifications of the commodity must also be fully settled. After giving prior notice, either party can cancel the contract before the manufacturing party has begun its work. Once the work starts, the contract cannot be cancelled unilaterally. Istisna can be used for providing the facility of financing the manufacture or construction of houses, plants, projects and building of bridges, roads and highways.

In Malaysia Istisna is used for Bridging Financing, Contract Financing, Plant \& Machinery Financing, Property Financing, Project Financing, Shop House Financing, Syndicated Financing etc. Pakistani Islamic banks using this product in House Construction and Installation of an air conditioner plant in the client's factory, Building a Bridge or a Highway.

\section{Bay Bithamal Ajjal}

This is credit sale contract. This contract refers to sale of goods at a price, which include profit margin that is agreed by both parties. This two parties and three parties contract. In two parties contract the Bank sell goods to client at cost plus profit on deferred payment basis. The client can pay lump sum in future or in installment. In three parties contract the bank purchased client required asset from supplier (vendor) and sell it to client as per above mentioned terms. BBA is commonly used for letter of credit creation and other usages are, purchase of fixed assets (land, building, machinery and computers), working capital financing and for trade financing.

In Malaysia Bay Bithamal Ajal (BBA) is used for Credit Card Creation, Letter of Credit, Negotiable Debt Certificate, Term Financing, Tour Financing, Umrah Financing, Working Capital Financing, Shop Housing Financing, Syndicated Financing, Share Financing, Revolving Credit Financing, Project Financing, Property Financing, Personal Financing, Asset Financing, Land Financing, Floor Stocking Financing, Education financing, House Financing, Equipment Financing, Contract Financing, Computer Financing, Club Membership Financing, Bridging Financing and Cash line Facility etc. BBA is not very common in Pakistan.

\section{Bay Al-Inah}

Bay al-inah is generally known as sale based on the transaction of Nasi'ah (delay). The (prospective) debtor sells to the (prospective) creditor some object for cash which is payable immediately; the debtor immediately buys simultaneously the same object for a greater amount for a future date. Refers to when bank purchases a commodity from its client on a spot basis and sells it back to the client at a cost plus price and on a differed basis. Bay-al-inah is used for credit card creation and also for issuance of bond with the combination of Bay-al-dayn, other areas of application are short-term working capital financing and shortterm personal finance. This is two party and three party contracts.

In Malaysia Bay al-inah is used for Cash line Facility, Personal Financing, Share Financing, Revolving Credit Facility, Credit Card Creation, Malaysian Islamic Treasury Bills, Negotiable Notes and Government Investment Issues etc.

Pakistani Banks are not using Bay al-inah in their banking practices.

\section{Bay Al-Dayn}

If a person has a debt receivable and he wants to sell it at a discount, as normally happens in the bill of exchange, it is termed in Shariah as Bay'-al-dayn. This mainly used for three type of financing, bill of exchange (discounting bill), Factoring (selling receivables) and issuance of bond. Bai-al-dayn is being used for discounting bills of exchange as a means of working capital finance, for factoring and financing of imports and exports.

In Malaysia Bay al-dyan is used for Export Credit Refinancing, Accepted Bills, Factoring Facility and Block Discounting etc. Pakistani Banks are not using Bay al-dayn in their banking transaction.

\section{RESEARCH METHODOLOGY}

Primary and Secondary data is used for this research. The sources of secondary data are books, research material and journal while primary data is collected by using questionnaire and interviews. The population is bankers working in Islamic banks in Lahore, Sialkot (Pakistan) and Alor Star, Jitra (Malaysia). Respondents/Target population comprised of both genders. Sample is collected from 3 banks in Pakistan while 7 Islamic banks were selected from Malaysia.

\section{Sample Size}

100 respondents were selected for this research at comprising 50 respondents from each country.

\section{Research Design}

The qualitative method (questionnaire) is used for this research. The questionnaire is developed based on the literature and the research objective. These questionnaires were self-administered i.e. they were personally distributed and collected. Those parts that were not clear personally explained. The validity and reliability of the questionnaires were assured. As the questionnaire were self-collected. Statistical Package of Social Science (SPSS) for further analysis.

\section{RESULTS}

\section{Correlations Results from Pakistan and Malaysia}

\begin{tabular}{lcccccc}
\hline \multicolumn{1}{c}{ Pakistan } & \multicolumn{3}{c}{ Malaysia } \\
\hline Variables & N & Means & $\begin{array}{c}\text { Correl } \\
\text { ation }\end{array}$ & N & Means & $\begin{array}{c}\text { Correla } \\
\text { tion }\end{array}$ \\
\hline mpromotion & 50 & 2,8367 & & 50 & 2,7639 & \\
mproduct & 50 & 2,6333 &, 049 & 50 & 2,8837 &, 247 \\
mpreference & 50 & 3,0160 &,- 067 & 50 & 2,7889 &, 067
\end{tabular}




\begin{tabular}{lllllll} 
mknowledge & 50 & 4,1700 &, 200 & 50 & 3,5561 &, 112 \\
mperformance & 50 & 3,0918 &, 236 & 50 & 3,2500 &, 338 \\
mproblem & 50 & 2,7292 &, 091 & 50 & 2,6111 &, 101 \\
minfrastructure & 50 & 3,0306 &,- 095 & 50 & 2,9063 &, 072 \\
\hline
\end{tabular}

* Correlation is significant at the 0.05 level (2-tailed).

** Correlation is significant at the 0.01 level (2-tailed).

\section{Interpretation}

The statistical results indicate that negative correlation between preference and promotion. This suggests that although there is a high preference for Islamic banking products, but promotion exists less or few promotion activities to promote Islamic banking products. But promotion has positive correlation with product, performance, problem and knowledge. This shows high promotion improve the performance of Islamic banks, create more awareness about Islamic banking products. The negative correlation between preference indicate although the preference of Islamic banks is high but still Islamic banks face challenges like untrained staff and low research and development in this area. Performance has negative correlation with negative with knowledge while positive with products, preference and promotion. The negative correlation shows the performance of Islamic banks is good but still people do not have knowledge about Islamic banking products. The high correlation of problem with knowledge and performance indicate that high research and development and well trained staff can increase the knowledge/awareness about Islamic banking and this definitely improve the performance of Islamic banking. The negative correlation of infrastructure with most of the variables shows there is still need to government support and organized education system to enhance the productivity of Islamic banks.

\section{Interpretation}

The statistics results indicate that positive correlation of promotion, product, performance, knowledge and problem with respect to their other variables. This positive correlation shows that Islamic banking is smoothly and successfully working in Malaysia and performance level, awareness and product demand is high. Most of bank staff is trained; they are working to design innovative and more acceptable products. There is high correlation of product with knowledge and performance this suggests not only the demand of the product is very high in Malaysia but also the performance of Islamic banks and awareness level of public is remarkable. There is still negative correlation of preference with problem and infrastructure. This negative relation suggests although the performance of Islamic banks in Malaysia is very high but there is need of government and education sector contribution and stronger implementation and monitoring from shariah supervisory board.

\section{FINDINGS}

Islamic banks in Malaysia have large range of products as compared to Pakistan. The main reason of this difference in product range is that Pakistan is following Imam Hanafi while Malaysia is following Imam Shafi. This difference in scholarly thoughts might be a reason few products are offered by Islamic banks in Pakistan compared to Malaysia.

If we see the difference with reference to product so there is significant difference of opinion about two products namely Bay alinah and bay al-dayn in both countries. Central bank and shariah advisory board in Pakistan do not permitted to use these two products but in Malaysia central bank permit to use them.

Our survey suggests that Ijara is most popular product in Pakistan as compared to any other product. This product is being used for car financing particularly. In Malaysia Murabaha is most common product. This product is used for trading, on cost plus profit basis. Malaysian Islamic banks use this product for equipment financing and working capital requirement.
Diminishing Musharaka is most commonly used for house financing in Pakistan. While Islamic banks in Malaysia normally used Bay Bithamal Ajil for house financing.

Malaysia is a very good market for Islamic banks and no doubt the hub of Islamic banking. Islamic banking products are easily available in Malaysia There is many Islamic banks offering different products. So the accessibility and availability of Islamic banking products is comfortable for customers. In Pakistan the products are not easily available accessible for customers.

Murabaha is most commonly used product for creation of letter of credit in Malaysia and Pakistan. The wakala is also being used for letter of credit.

The practitioners from both countries are agreed at this point that BBA, Ijarah and Murabaha are more profitable and less risky than Musharaka and Mudaraba. In Musharaka and Mudaraba the chances of moral hazard is very high due to asymmetric information and need extensive monitoring. This is a cause of high information cost and low profitability.

The lack of awareness of Islamic banking is very high in Pakistan as compared to Malaysia. A few promotions were used by Islamic banks in Pakistan while in Malaysia customers are knowledgeable about Islamic banking because banks promote them aggressively.

There is a need of government and education sector support to promote Islamic banking in both countries.

\section{CONCLUSION}

This survey was exclusively done to understand and compare Islamic banking practices in Pakistan and Malaysia.

Islamic banking financing techniques used in Malaysia and Pakistan. Malaysia has a large product line than Pakistan. This product difference is a cause of different approaches towards Islamic banking in both countries. Some products are being successfully running in Malaysia but not permitted in Pakistan. Murabaha is most popular product in Malaysia while Pakistan mostly prefers ijarah. Islamic banks in Pakistan generally used Musharaka, Mudarabah, Murabaha, Ijarah, Istisna, Wakala, Quard Hasan and Salam for product development. In Malaysia Islamic banks develop products on different basis. They have more options than Pakistan. They normally use Musharaka, Mudaraba, Murabaha, Ijarah, Istisna, Wakala, Quard Hasan, Bay al-inah, Bay aldayn, Wakala, Rahn, Kafala, Ujar and Salam.

With reference to different views from scholars about acceptability of product, there is big difference of opinion about two product Bay alinah and bay al-dayn in both countries. Central bank and shariah advisory board in Pakistan do not permit to use these two products because they feel that these products islamically are not fit to use but in Malaysia central bank permit to use them. Diminishing Mushrika is most commonly used for house financing in Pakistan While Islamic banks in Malaysia normally used Bay Bithamal Ajil for house financing. The conflict between different scholars is a big issue not only for Malaysia and Pakistan but for the whole world. The different Islamic scholars have different point of view about different Islamic banking products and other matters. That is a reason some products are permissible in Malaysia but not in Pakistan.

\section{REFERENCES}

Ahmad K. and M. M. Isa (2003). 'Causal relationship between Islamic and conventional Banking instruments in Malaysia', International Journal of Islamic Financial Services; 4(4).

Al-Arabi, M. A. (1966). 'Contemporary banking transactions and Islam's views thereon', Islamic Review London; 10-16.

Ariff, M. (1988). Islamic Banking: Asian Pacific Economic Literature, 2(2), pp. 48-64.

Council of Islamic Ideology (CII), Pakistan. (1983). 'Elimination of interest from the economy', in Ziauddin, Ahmed et al.

Erol. C. and R. El-Bdour. (1989). 'Attituded, Behaviour and Patronage Factors of Bank Customers Towards Islamic Banks: International Journal of Bank Marketing, Volume 7, No. 6, pp. 31-37. 
Gafoor A.L.M. (1996). Interest Free Commercial Banking: A S Noordeen, Kuala Lumpur.

Gerrard, P. and J. B. Cunningham. (1997) 'Islamic Banking: A Study in Singapore', International Journal of Bank Marketing, Volume 15, No. 6, pp. 204-16.

Haron, S. Ahmad, N. and S. L. Planisek. (1994) 'Bank Patronage Factors of Muslim and Non-Muslim Customers: International Journal of Bank Marketing, Volume 12, No. 1, pp. 32-40.

Haroon and Noraffifah A. (2000). The Effects of Conventional Interest Rates and Rate of Profit on Funds Deposited with Islamic Banking System in Malaysia: International Journal of Islamic Financial services, 1, No.3,

Iqbal, Zubair and Mirakhor, Abbas. (1987). Islamic Banking, International Monetary Fund: Occasional Paper 49, Washington D.C.

Irshad, S.A. (1964). Interest-Free Banking: Orient Press of Pakistan, Karachi

Islamic Banking Bulletin, State Bank of Pakistan, January to March 2018 http://www.sbp.org.pk/ibd/bulletin/2018/Mar.pdf

Islamic banks driving Malaysian banking sector growth-RAM http://www.theedgemarkets.com/article/islamic-banks-driving-malaysianbanking-sector-growth-\%E2\%80\%94-ram

Range of Islamic Banking Products and Services in Malaysia Deposit: Bank Negara Malaysia (2006).

Shabbir h. Kazmi. (2002). Islamization of Financial System in Pakistan: State Bank of Pakistan

Sudin Haron. A Comparative Study of Islamic Banking Practices.

Uzair, Mohammad ( 1955). An Outline of 'Interestless Banking: Raihan Publications, Karachi. 